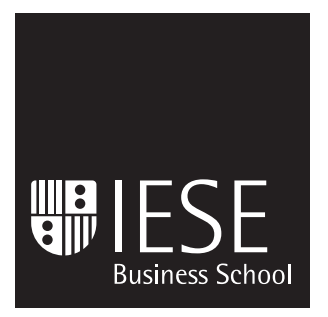

University of Navarra
Working Paper

WP no 653

September, 2006

\title{
PASS THROUGH OF EXCHANGE RATES \\ TO CONSUMPTION PRICES: WHAT HAS CHANGED AND WHY?
}

\author{
José Manuel Campa \\ Linda S. Goldberg
}


The CIIF, International Center for Financial Research, is an interdisciplinary center with an international outlook and a focus on teaching and research in finance. It was created at the beginning of 1992 to channel the financial research interests of a multidisciplinary group of professors at IESE Business School and has established itself as a nucleus of study within the School's activities.

Ten years on, our chief objectives remain the same:

- Find answers to the questions that confront the owners and managers of finance companies and the financial directors of all kinds of companies in the performance of their duties

- Develop new tools for financial management

- Study in depth the changes that occur in the market and their effects on the financial dimension of business activity

All of these activities are programmed and carried out with the support of our sponsoring companies. Apart from providing vital financial assistance, our sponsors also help to define the Center's research projects, ensuring their practical relevance.

The companies in question, to which we reiterate our thanks, are:

Aena, A.T. Kearney, Caja Madrid, Fundación Ramón Areces, Grupo Endesa, Royal Bank of Scotland and Unión Fenosa.

http://www.iese.edu/ciif/ 


\title{
PASS THROUGH OF EXCHANGE RATES TO CONSUMPTION PRICES: WHAT HAS CHANGED AND WHY?
}

\author{
José Manuel Campa* \\ Linda S. Goldberg**
}

\begin{abstract}
In this paper, we use cross-county and time series evidence to argue that retail price sensitivity to exchange rates may have increased over the past decade. This finding applies to traded goods, as well as to non-traded goods. We highlight three reasons for changing pass through at the level of retail prices of goods. First, pass through may have declined at the level of import prices, but the evidence is mixed over types of goods and countries. Second, there has been a large expansion of imported input use across sectors. This means that the costs of imported goods as well as home tradable goods have heightened sensitivity to import prices and exchange rates. The final channel we consider is whether there have been changing sector expenditures on distribution services, with the direction of change negatively correlated with pass through into final consumption prices. We find that this channel, which has been a means of insulating consumption prices from import content and exchange rates, has not systematically changed in recent years. The balance of effects weighs in favor of increased sensitivity of consumption prices to exchange rates, even if exchangerate pass-through into import prices has declined for some types of goods.
\end{abstract}

* Professor of Financial Management, Grupo Santander Chair in Financial Institutions, IESE

** Federal Reserve Bank of New York and NBER

JEL Classification: F3, F4

Keywords: Exchange rate, pass through, import prices, distribution margins, consumer prices, imported inputs.

The views expressed in this paper are those of the individual authors and do not necessarily reflect the position of the Federal Reserve Bank of New York or the Federal Reserve System. Address correspondences to Jose Campa at jcampa@iese.edu or Linda S. Goldberg, Federal Reserve Bank of NY, Research Department, 33 Liberty St, New York, N.Y. 10045. Tel: 212-720-2836; fax: 212-720-6831; email: Linda.Goldberg@ny.frb.org. We are grateful for the comments provided by Chatib Basri, Kiyotaka Sato, Takatoshi Ito, and participants of the NBER East Asian Seminar in Economics, held June 2006 in Kona, Hawaii. Campa acknowledges the financial support of Fundación Ramón Areces. 


\section{PASS THROUGH OF EXCHANGE RATES TO CONSUMPTION PRICES: WHAT HAS CHANGED AND WHY?}

\section{Introduction}

Both traded and no traded goods prices can be sensitive to exchange rate movements. There are a number of forces that contribute to less than complete pass through of exchange rates into the final consumption prices of imported goods. First, pass through into prices at the border is incomplete, and varies considerably across goods and across countries. Second, distribution services, like local storage, transportation, and retail costs, provide some insulation of consumption prices of traded goods, both by diluting the import content of the final consumption good and because distributors may actively adjust profit margins to absorb currency fluctuations. For home produced tradable goods, production costs are expected to become more sensitive to exchange rates and import prices as production increasingly relies on imported components. Indeed, a producer of tradable goods achieves such production cost sensitivity both through his own reliance on imported components and through the reliance of his domestic suppliers and distributors on imported inputs. Imported goods play a role, directly introducing sensitivity to exchange rates in the domestic economy through costs, as in Campa and Goldberg (2006), or alternatively by keeping pass through into import prices low in a model of foreign exporting firms selling intermediate goods to domestic producers who compete with no traded goods producers, as argued by Bacchetta and van Wincoop (2003). ${ }^{1}$

In this paper, we consider the evolution over the past decade in the predicted sensitivity of consumption prices of imported and domestically-produced goods with respect to exchange rates. For this work, we focus on changes in distribution margins and imported inputs use, as well as on pass through into import prices at the border for five broad categories of goods: manufactured, non-manufactured, food, energy, and raw materials. Thus, we build on Campa and Goldberg (2006), who explored the role of the distribution sector and imported inputs in levels of CPI sensitivity to exchange rates across twenty-one OECD countries. That study documented that distribution expenditures associated with goods consumed by households are between 30 and 50 percent of the purchasers' prices. These distribution expenditures are dominated by wholesale and retail sector costs, with transportation and storage costs relatively low except in the case of various raw materials and mining industries. In tradable goods production, imported inputs are shown to account for between 10 and 48 percent of the final price. No tradable goods are

\footnotetext{
${ }^{1}$ Corsetti and Dedola (2005) make related arguments in a different production chain and pricing set-up.
} 
produced with lower shares of imported inputs, ranging from 3 percent in the United States to 22 percent in Hungary. Using this evidence across countries within a calibrated model, Campa and Goldberg (2006) found that predicted and actual CPI sensitivity to exchange rate movements are low, often below 10 percent of any exchange rate change.

Yet that study did not address changes over time in the effects of exchange rates on the consumption prices of different types of goods. With distribution expenditures partially insulating final consumption prices from import price changes at the border, consumption price sensitivity to exchange rates can rise if the structure of the retail and distribution sector leads to lower distribution costs. In particular, we ask whether there has there been something like a "Walmart effect" influencing exchange rate pass through, whereby expenditure on such services declines as large-box retailers and distributors are increasingly present in local markets.

One issue is the potential for changing pass through into the prices of imports at the border. Some studies present evidence that pass-through into the import prices of industrialized countries has declined in the past decade, particularly on finished goods [Marazzi, Sheets, and Vigfusson (2005), Otani, Shiratsuka, and Shirota (2005), Frankel, Parsley and Wei (2005)], while other studies dispute the magnitude and significance of such changes [Campa and Goldberg (2005), Campa, Goldberg, Mínguez-González (2005), Ihrig, Marazzi, and Rothenberg (2006), Daly, Hellerstein, and Marsh (2006), Thomas and Marquez (2006)].

Another relevant issue is the growth of globalization of production over the recent decade. If more imported components are used in production, and these components are priced as other imports at the border, then there is more opportunity for local costs to be sensitive to exchange rates. This growth in imported inputs could raise the sensitivity of final consumption prices to exchange rates.

In this paper, we pull together evidence on these three sources of changing pass through into consumption prices of types of goods using data drawn from eighteen countries. We compare the roles of expenditures on distribution services, use of imported inputs and components in production, and of changes in the rate of exchange rate pass through into border prices of goods, across countries, across sectors, and for pre- and post-1995 time periods. The analysis yields the following observations. Pass through into the prices of imports, at the border, is defined more by industry than by country. The notable exception is the United States, where pass through into import prices is unusually low. Pass through into import prices is noisiest and least precisely measured for energy imports. Pass through into import prices of manufactured goods and, less so, food prices, are the only categories measured with precision across countries. Evidence of declining pass through into the border prices of imports is concentrated within some manufactured goods categories [Marazzi and Sheets (2006), Campa, Goldberg, and Minguez-Gonzalez (2005)], but only for some countries.

Across countries and industries, distribution expenditures have a large industry-specific component but are not trending in a consistent direction across these industries. Imported input use likewise has industry characteristics, but -unlike distribution expenditures- trend changes have been significant and widespread. Imported input use has tended to grow over time, both across countries and across industries. These findings together will suggest that changes in distribution margins have not been the key contributor to changing pass through into consumption prices of goods over the past decade. By contrast, the significant expansion of imported input use, including its use in distribution services, has increased the predicted sensitivity of retail prices of imported goods and other tradable goods to exchange rates. 
It is important to point out that our exercise is one of generating imputed changes in prices associated with exchange rate movements. This exercise is one of "all else equal". The exercise shows pressures on prices that are generated by exchange rates. However, these price pressures may not be observable in realized consumption price data. As Gagnon and Ihrig (2004) compellingly argue, and Gust and Sheets (2006) build into general equilibrium models, the inflationary impetus from a domestic currency depreciation may be met with monetary tightening. In this case, some of the inflationary pressures from depreciation are offset by policy.

Section II begins our exposition by presenting evidence on industry-specific exchange rate pass through into import prices and the (more sparse) evidence available on pass-through into consumption prices at the level of particular industries. In Section III we delve into the industryspecific features of distribution margins and imported input use, and focus specifically on decomposing patterns into ones associated with specific countries, industries, and points in time. Section IV pulls together this information and evidence on exchange rate pass through into import prices to generate predicted values for the consumption price sensitivity to exchange rates of different types of goods across countries. Section V concludes by summarizing key findings and discussing implications for trade balance adjustment to exchange rates.

\section{Import Price Elasticities with Respect to Exchange Rates}

There is a large literature that has looked at the extent to which exchange rate changes affect import prices of goods. Most of these previous studies generally have found that pass-through is incomplete, implying that import prices are less volatile than exchange rates. Goldberg and Knetter (1997) present a review of the literature in this area and concluded that pass-through into U.S. import prices was on the order of 50 percent. Large variations around this estimate occur by industry. Antzoulatos and Yang (1996), Yang (1997) and Olivei (2002) all perform estimation of pass-through rates into import prices at the industry level and conclude that pass-through varies across industries. The existing evidence has been obtained by either focusing in a subset of narrowly defined industries, using data at the firm or product level (micro studies) or, more broadly, by looking at a cross-section of relatively aggregated industry statistics (industry studies).

Micro-oriented studies generally focus on pass-through from one country's firms into another's and concentrate on a particular product or industry. For example, Feenstra (1989) and Gron and Swenson (1996) examined the pass-through of movements of the yen into U.S. import prices for Japanese shipments of cars, trucks and motorcycles. Gil-Pareja (2003) and Goldberg and Verboven (2001) also focus on the degree of pass-through in the automobile industry by looking at detailed product imports from different countries. In other industries, Bernhofen and $\mathrm{Xu}$ (2000) examined the exchange rate pass-through into U.S. petrochemical imports from Germany and Japan and Blonigen and Haynes (2002) looks at Canadian exports of iron and steel into the United States.

The cross-industry studies focus on import prices for more than one industry at a time, often with more aggregated data than found in the micro-oriented studies. Yang (1997), Pollard and Coughlin (2005) provide estimates of pass-through at broader industry classifications for imports in the manufacturing sector in the U.S. Similar evidence for five industry categories is presented for OECD countries in Campa and Goldberg (2005, 2006), Marazzi, Sheets, and Vigfusson (2005), Ihrig and Gagnon (2006) and, for European Union countries in Campa, Goldberg and Mínguez-González (2006). Across the OECD countries, industry considerations, 
and particularly the sector composition of a country's imports, have been more important than macroeconomic volatility in explaining changes in exchange rate pass through into aggregated import prices.

Table 1 reports estimated pass-through rates into import prices for all imports and for five broad industry categories across 16 countries. The reported coefficients are the estimated passthrough rates from a regression of changes in import prices on changes in nominal exchange rates and foreign prices using quarterly data for the period 1976:1 to $2004: 1{ }^{2}$ The reported estimates of pass through of exchange rate changes are the contemporaneous effect and the accumulative one-year impact from an exchange rate shock. These estimates come from a partial-adjustment model of the form

$$
\Delta p_{t}^{j}=\alpha+\sum_{i=0}^{-4} a_{i}^{j} \Delta e_{t-i}^{j}+\sum_{i=0}^{-4} b_{i}^{j} \Delta w_{t-i}^{j}+c^{j} \Delta g d p_{t}^{j}+\vartheta_{t}^{j}
$$

where $p_{t}$ are local currency import prices or the local consumer price index, $e_{t}$ is the exchange rate, $w_{t}$ is the foreign production costs, $g d p_{t}$ is real GDP, and the final term is the regression residual. The short-run relationship between exchange rates and the respective price series of country $j$ is given by the estimated coefficient $a_{0}^{j}$. The long run elasticity is given by the sum of the coefficients on the contemporaneous exchange rate and four lags of exchange rate terms $\sum_{i=0}^{-4} a_{i}^{j}$. While the theoretical antecedents of this equation suggest a log-levels relationship among variables, for estimation, the variables in these equations are first differences in logarithms to control for the possibility of unit roots (Campa and Goldberg, 2006, and Osbat, 2006).

Across the eighteen countries for which pass through rates are presented in Table 1, the (unweighted) average pass-through elasticity of import prices is 0.59 . Consistent with the findings of prior studies, most industries exhibit a striking degree of partial pass through. In the "all imports" category the hypothesis of zero exchange rate pass-through is rejected for more than half of the countries. Across industries, pass-through rates equal to 1, i.e. complete pass-through, are strongly rejected for Manufacturing and for Food.

Pass through is smaller in Manufacturing than in commodities such as Energy and Raw-Materials. The precision of the estimates also is tightest for Manufacturing and for Food, with dispersion of estimated rates of pass-through across countries lowest for these categories. Campa and Goldberg (2005) reached similar conclusions for both short-run and long-run pass-through rates in the OECD countries. These differences across industries also occur at more disaggregated levels within manufacturing, as Yang (1997) and Pollard and Coughlin (2005) show for manufacturing industries in the United States, and Campa, Goldberg, and Minguez-González (2006) show for the euro-area

\footnotetext{
${ }^{2}$ The sample period begins later for Netherlands (1977:2), Norway (1978:2), Portugal and Sweden (1980:2), Australia and Belgium (1981:2), Italy (1982:2), Denmark and New Zealand (1987:3), and Hungary (1995:2) and ends earlier for Netherlands (1997:4), Portugal (1998:4), Austria (1999:4), Denmark and New Zealand (2002:4). France is missing data from 1987:1 to 1996:1.
} 
countries. Pass-through into the import prices of Non-Manufactured goods, Energy, and Raw Materials appears to be poorly measured by the basic estimating equation. ${ }^{3}$

\section{Table 1}

Pass-through- rates into Industry Import Price Indices

\begin{tabular}{|c|c|c|c|c|c|c|}
\hline & All Imports & Food & Energy & Raw Materials & Manufacturing & Non-Manufacturing \\
\hline $\begin{array}{l}\text { Australia } \\
\text { Austria }\end{array}$ & $\begin{array}{l}0.67^{*}+ \\
0.10\end{array}$ & $\begin{array}{l}0.35^{*}+ \\
0.06\end{array}$ & $\begin{array}{l}-0.69+ \\
2.24\end{array}$ & $\begin{array}{l}0.43^{*}+ \\
1.74\end{array}$ & $\begin{array}{l}0.93^{*} \\
-0.32+\end{array}$ & $\begin{array}{l}0.06+ \\
1.50\end{array}$ \\
\hline Belgium & 0.68 & 0.55 & -0.70 & $1.72^{*}$ & 0.43 & 0.51 \\
\hline Denmark & $0.82^{*}$ & $0.99^{*}$ & 3.50 & $1.14^{*}$ & $0.57^{*}+$ & $1.61^{*}$ \\
\hline Finland & 0.77 & 0.83 & 1.46 & 0.28 & 0.74 & 1.08 \\
\hline France & $0.90^{*}$ & $1.41^{*}$ & 1.89 & -- & $0.99^{*}$ & 1.27 \\
\hline Germany & $0.80^{*}$ & $0.48^{*}+$ & $2.72^{*}$ & $1.12^{*}$ & $0.42^{*}+$ & $1.54^{*}$ \\
\hline Hungary & $0.78^{*}$ & $0.63^{*}$ & 0.89 & -0.00 & $0.79^{*}+$ & 0.67 \\
\hline Ireland & -0.06 & $1.23^{*}$ & $1.78^{*}$ & $2.06^{*}$ & $1.19^{*}$ & $1.70^{*}$ \\
\hline Italy & $0.35+$ & $0.81^{*}$ & -.80 & 0.76 & $0.56^{*}+$ & 0.07 \\
\hline Netherlands & $0.84^{*}$ & $0.54^{*}+$ & 2.19 & $1.72^{*}$ & $0.32^{*}+$ & $1.44^{*}$ \\
\hline $\begin{array}{l}\text { New } \\
\text { Zealand }\end{array}$ & $0.22+$ & $0.23+$ & 0.27 & $-0.04+$ & $0.24+$ & 0.18 \\
\hline Norway & $0.63^{*}$ & $0.15+$ & -0.69 & 0.69 & $0.61^{*}$ & 0.07 \\
\hline Portugal & $1.08^{*}$ & $1.07^{\star}$ & 0.79 & $1.41^{*}$ & $1.02^{*}$ & 0.85 \\
\hline Spain & $0.70^{*}$ & 1.01 & -0.01 & $1.23^{*}$ & $1.06+$ & 0.61 \\
\hline Sweden & $0.38^{*}+$ & $0.85^{\star}$ & $-1.64+$ & $0.11+$ & $0.66^{*}+$ & $-0.66+$ \\
\hline U. Kingdom & $0.46^{\star}+$ & $0.52^{*}+$ & 0.39 & $0.47^{*}+$ & $0.46^{*}+$ & $0.39+$ \\
\hline $\begin{array}{l}\text { United } \\
\text { States }\end{array}$ & $0.42^{*}+$ & $0.21+$ & 0.20 & $0.44^{*}+$ & $0.44^{*}+$ & 0.33 \\
\hline Average & 0.59 & 0.66 & 0.77 & 0.90 & 0.62 & 0.77 \\
\hline $\begin{array}{l}\text { Standard } \\
\text { Deviation }\end{array}$ & 0.30 & 0.39 & 1.42 & 0.67 & 0.36 & 0.68 \\
\hline
\end{tabular}

*Significantly different from zero (5\%), + Significantly different from one (5\%). Most data are quarterly, spanning 1975 through the end of 2004. Data sources: nominal exchange rate and consumer prices come from the IFS; import price comes from the OECD. Specific start and end dates by country are detailed in the data appendix. Long-run elasticities (four quarters) shown.

Recent studies have debated whether pass through of exchange rates into import prices may have declined since 1997, particularly for the United States [Marazzi et al. (2005), Ihrig et al. (2006)]. Campa, Goldberg, and Minguez-González (2005) argue that the evidence is mixed across European countries. We replicate these tests for fifteen of the eighteen countries ${ }^{4}$ of Table 1 and find that it is difficult to make a case that pass through into import prices has systematically declined. Typically, the relationship between exchange rates and the local currency import prices of Energy, Raw Materials, and Non-Manufactured goods are found to be noisy and unstable. It is difficult to make definitive statements about whether pass-through

\footnotetext{
${ }^{3}$ There are many reasons why the pass-through estimation equation can generate poor results. One of these reasons is that the proxies for production costs may be poor. Another reason could be codetermination of exchange rates and the prices of some goods. In recent years, the dollar and petroleum prices have exhibited stronger comovement than in the preceding decade.

${ }^{4}$ We are able to compare a pre-1995 period with the period from 1995 to the present for all countries, except France and the Netherlands for which the import price data ends in 1997 and Hungary for which the available data begins in 1993.
} 
rates have altered meaningfully for these sectors. By contrast, for Manufactured goods estimates of exchange rate pass through are more informative. We observe some instances of increasing pass through of exchange rate movements into import prices and other instances of declining pass through as we look across the sample of countries. Importantly, we stress here that the presumption that pass-through rates have systematically declined across countries, and across a wide spectrum of goods, is not supported. It is not yet appropriate to conclude that persistent change has occurred in the distribution of pass through into import prices of manufactured goods.

\section{Mapping imported inputs and distribution margins into consumption prices of goods}

One goal of the analysis is to understand the feedback between exchange rate changes and stimuli to consumption prices or goods across countries. ${ }^{5}$ In order to move from exchange rate sensitivity in the border prices of goods to sensitivity in retail prices, analyses need to account for the role of the distribution sector and imported inputs used in production. For this purpose, we use a basic approach of a two country model with wage stickiness and monopolistically competitive producers. Our specific formulation closely follows Campa and Goldberg (2006), and the prior studies discussed therein.

\section{A. The mapping}

This approach follows a utility-based framework that explicitly tracks the degree of substitutability of imported and domestic products, and presents the explicit cost functions faced by producers. C.E.S. utility functions are assumed over no traded $(n)$ and traded goods $(t)$ consumption, with both sectors producing a continuum of varieties with similar elasticities of substitution, $\theta$. Prices for any good $i$ are a markup over costs $c_{t}(i)$, with the markup rate as $\theta /(1-\theta)$. Consumption of tradable and no tradable products are also governed by a constant elasticity of substitution $\phi$. Home $(h)$ and foreign $(f)$ tradable goods are imperfect substitutes in consumption, with an elasticity of substitution of $\phi_{T}>1$. Bringing one unit of good $i$ where $i \varepsilon$ ( $h$, $f, n)$ to consumers requires units of a basket of differentiated no traded goods for distribution services. ${ }^{6}$ We denote these distribution costs per unit of output by $\mu_{t}(i: e)$, where this basket of differentiated no traded goods includes expenditures on wholesale and retail sector services, as well as expenditures on transportation and storage. These distribution expenditures are permitted to be sensitive to the exchange rate $e$, which is defined as the domestic cost per unit of foreign exchange. Per unit production requires domestic labor and imported inputs. Labor inputs required per unit of output are inversely related to sector productivity parameters $Z_{i}$. $W_{t}$ refers to the wage per unit of labor at home, and $W_{t} *$ refers to foreign wages. Productivity parameters as well as domestic and foreign wages are assumed sticky over the relevant pricing horizon. Imported input shares per unit of output are denoted by $\mu_{t}(i: e)$, for home tradable goods and home no tradable

\footnotetext{
${ }^{5}$ Another goal of the analysis of pass through and consumption prices of categories of goods is to understand the signal sent to consumers to induce expenditure switching between imported and home produced goods. This signal is a critical link in trade balance sensitivity to exchange rate fluctuations. See Goldberg and Tille (2006).

${ }^{6}$ Burstein, Neves, and Rebelo (2003) highlight the role that distribution margins can play in lowering exchange-rate pass-through into consumption prices.
}

6 - IESE Business School-University of Navarra 
goods. These imported cost shares also are sensitive to exchange rates. Foreign currency variables are indicated by superscript “*”. The pricing equations $P_{t}(i)$ for home no tradable goods $n$, home tradable goods $h$, and imported consumption goods $f$ are given by

$$
\begin{aligned}
& P_{t}(n)=\frac{\theta}{\theta-1} c_{t}(n)=\frac{\theta}{\theta-1}\left[\frac{W_{t}}{Z_{N}}+\mu_{t}(n: e) \frac{e W_{t}^{*}}{Z_{F}}\right] \\
& P_{t}(h)=\frac{\theta}{\theta-1} c_{t}(h)=\frac{\theta}{\theta-1}\left[\frac{W_{t}}{Z_{H}}+m_{t}(h: e) \cdot P_{t}(n)+\mu_{t}(h: e) \frac{e W^{*}}{Z_{F}}\right] \\
& P_{t}(f)=\frac{\theta}{\theta-1} e_{t} c_{t}^{*}(f)=\frac{\theta}{\theta-1}\left[\frac{e W_{t}^{*}}{Z_{F}}+m_{t}(f: e) \cdot P_{t}(n)\right]
\end{aligned}
$$

Differentiating equations (1) through (3), we derive expressions for exchange-rate pass -through elasticities into home tradable, home no tradable, and imported goods prices. The respective passthrough rates into the consumption prices of these goods are shown in equations (4) through (6). Notationally, $\eta^{a, b}$ terms denote elasticities of $a$ with respect to changes in $b$.

$$
\begin{gathered}
\eta^{P(n), e}=\frac{\partial P(n) / \partial e}{P(n) / e}=\left(1+\eta^{u_{t}(n: e), e}\right)\left[\frac{\mu_{t}(n: e) \frac{e w^{*}}{Z_{F}}}{c_{t}(n)}\right]=\frac{\theta}{\theta-1}\left(1+\eta^{u_{t}(n: e), e}\right)\left[\frac{\mu_{t}(n: e) \frac{e w^{*}}{Z_{F}}}{P_{t}(n)}\right] \\
\eta^{P(h), e}=\frac{\partial P(h) / \partial e}{P(h) / e}=\frac{\theta}{\theta-1}\left[\left(\eta^{P(n), e}+\eta^{m(h), e}\right) \frac{m(H: e) P(n)}{P_{t}(h)}+\left(1+\eta^{u_{t}(h: e), e}\right) \frac{\mu(h: e) \frac{e W^{*}}{Z_{F}}}{P_{t}(h)}\right] \\
\eta^{P(f), e}=\frac{\partial P(f) / \partial e}{P(f) / e}=1-\frac{\theta}{\theta-1} \frac{\left(m(f: e) P_{t}(n)\right)}{P(f)}\left[1-\left(\eta^{m(f), e}+\eta^{P(n), e}\right)\right]
\end{gathered}
$$

Equation (4) shows that pass through into the consumption price of no tradables occurs only when this sector has cost sensitivity to exchange rates through its use of imported inputs. Some of the exchange rate pass through in no tradables can be mitigated to the extent that no tradables producers can substitute away from these imported inputs as they become more expensive, $\eta^{\mu,(n: e), e}<0$.

Equation (5) shows exchange-rate pass through into the consumption prices of tradables produced in the home market. This pass through occurs both because home tradables use imported inputs and also because sector expenditures on no traded distribution services can be sensitive to exchange rates. Such sensitivity can be passive, because no tradables prices can respond to exchange rates through imported inputs (as in 4). More active sensitivity arises if distributors strategically adjust the markups they take on home tradables that compete with 
imported brands. This phenomenon, called double marginalization, is explored in Campa and Goldberg (2006) and Hellerstein (2004).

Pass through into the consumption prices of imports, Equation (6), differs from border price sensitivity of imports. For the derivations of equations (4) through (6), exchange-rate pass through at the border is assumed to be complete, i.e. equal to one. If pass through at the border is different than one, the actual border pass through rate simply multiplies equations (4) through (6) Whatever the border price sensitivity, local expenditures on distribution dilute the import content of this consumption good (the first term), even more so if distributors also actively reduce the margins changed during home currency depreciations to limit changes in market shares of the products being distributed. One force magnifying the pass through of exchange rates, and therefore working in the opposite direction, is that from equation (4) whereby distribution costs rise if these services rely on imported inputs into production and have costs that are sensitive to exchange rates.

Equations (4) to (6) also show the impact that increases in the distribution margins have on the expected pass-through rates of a given change in imported prices of final goods or intermediate inputs in final consumer prices. In general, increases in the share of the distribution sector in the final price of a good, decrease the impact on the final consumption price of the good. For non-traded goods, this effect occurs mainly through imported inputs used in production. For domestically-produced traded goods, the impact in equation (5) occurs through a decrease in the foreign value added part of the product. Moreover, as the share of imported inputs in the production of the good increases, changes in border prices of imported products have a higher percentage impact in the production cost of domestically produced goods. This results in higher pass-through into consumer prices.

The existing evidence on pass-through into import prices at the aggregate level suggests that the pass-through may have declined in the last decade, at least in developed countries [see Pollard and Coughlin (2005), Marazzi et al. (2005) and Olivei (2002)]. We have argued that such evidence is not definitive and requires further monitoring. Yet, despite this possible change in pass-through at the border, the outcome of the debate does not impinge on the key roles that imported inputs and distribution costs have in the final impact of import prices on consumer prices. Increases in imported inputs and in vertical trade that have occurred in the last decade would suggest a rise in import price pass-through. Increases in vertical trade also raise the likelihood that imported products have value added that originates in the home market. For example, U.S. imports of cars from Canada could contain engines that were first produced in the United States, exported to Canada, and ultimately re-exported to the United States. The result is a smaller share of Canadian value-added in U.S. imports, and less Canadian content to be acted upon by exchange rate movements. In this context, we could expect declining sensitivity to exchange rate changes of auto import prices from Canada as Canadian content falls. At the same time, increases in the imported input component of domestically produced goods imply a higher exposure of domestically produced products to exchange rate changes and a higher pass-through from import prices into final consumer prices. ${ }^{7}$ To quantify the relative size of each of these effects and the insulating role of the distribution sector, in the next section we examine the evolution of imported input shares and distribution margins over the last decade.

\footnotetext{
${ }^{7}$ Feenstra (1998) and Rauch (1999) show the increasing role that the vertical integration of production across borders has on international prices and trade. This discussion has not dealt with the issue of transfer pricing, which pertains to intra-firm pricing policies. or instance, a multinational may differentially price sales of goods to subsidiaries versus to unrelated parties.
} 


\section{B. Patterns in Imported Input Use and Distribution Expenditures}

We measure the share of imported inputs and distribution expenditures for industries by using country-specific input-output tables. ${ }^{8}$ Our full sample of imported input data spans 16 countries, 59 homogeneous manufacturing, primary-industry, and service industry groupings, and 1 to 2 years per country-industry observation. ${ }^{9}$ The data on distribution margins span all but one of the same countries, but with narrower availability in terms of industries. The reduced availability occurs because, in some cases, service industry inputs into industry production are unavailable. Details on data construction and availability are provided in Appendix Table 2.

Our analysis extends information reported in Campa and Goldberg (2006), which looked at the disaggregated data across countries. That study observed that industries with the highest imported input share are Coke, Refined Petroleum Products, and Nuclear Fuel Manufacturing. Within the manufacturing sector, the next highest imported input shares are in Computers and Communication Equipment, at around 50 percent. More generally, industries involved in services, agriculture, and commodity production have much lower shares of imported inputs than industries in manufacturing. For instance, Real Estate services, and Forestry, Logging and Related Services have average imported input shares between 6 percent and 14 percent of total costs, respectively. By contrast, almost all manufacturing industries have imported input shares above 20 percent. The industry within manufacturing with the lowest imported input share is Food and Beverage manufacturing.

The dispersion of imported input shares in production differs significantly by country. In general, larger countries have lower shares of imported inputs while smaller countries have higher shares. The United States has by far the lowest ratio of imported inputs into production of all countries in our sample. Ireland, with 51 percent, has by far the largest reliance on imported inputs with other smaller countries like Belgium, Hungary and the Netherlands also heavily reliant on imported parts and components.

More formally, we consider the extent to which industries versus countries versus time explain the prevalence of import input use. We run regressions using 1,394 imported share observations, covering 59 industries and 16 countries. Variance decompositions are used to identify the portions of the observational variance within this data base that are attributable to industry fixed effects, country fixed effects, or time dummies. With the exception of France, Ireland, Norway, Portugal, Spain, and the United Kingdom, each country included in the sample has two years (typically five years apart) of imported input data.

The full regression specification accounts for 70 percent of the variation in imported input use (Table 2). In order of importance, imported input use is determined first by industry identity, then country, then by time. Having already discussed industry and country highlights, it is interesting to focus attention on time trends in imported input use across countries. Of the 57 industries with enough observations to run a regression, 16 industries had time trends that were statistically significant, at a 10 percent level. All of these trends were positive. ${ }^{10}$ On average, the industries with significant trends had imported input use increase by 0.9

\footnotetext{
${ }^{8}$ Details on construction methods are in Campa and Goldberg (2006).

${ }^{9}$ Compared with Table 1, we drop Australia and Greece from the analysis due to lack of input-output information to allow us to compute the data on imported inputs.

10 The industries with significant time trends include food, energy extraction and refining, manufacture and servicing of computers and other machinery, and some service industries.
} 
percentage points per year. Manufacturing industries: Coke, refined petroleum products and nuclear fuel had the largest (statistically significant) increase in imported input share, rising 3.4 percentage points per year, on average. Real estate activities had the smallest significant increase, averaging 0.2 percentage points per year.

\section{Table 2}

Imported Input Variance Decomposition

\begin{tabular}{|l|c|c|c|}
\hline \multicolumn{1}{|c|}{ Adjusted R-squared for the full regression specification with all dummy variables } & 0.70 \\
\hline & $\begin{array}{c}\text { Adj. R-squared for } \\
\text { regression excluding each } \\
\text { set of dummies }\end{array}$ & $\begin{array}{c}\text { Adj. R-squared for } \\
\text { regression with only each } \\
\text { set of dummies }\end{array}$ & $\begin{array}{c}\text { Percent of full regression } \\
\text { specification adjusted R2 } \\
\text { explained by each set of } \\
\text { dummies }\end{array}$ \\
\hline Industry dummies & 0.19 & 0.48 & 68.3 \\
\hline Country dummies & 0.60 & 0.19 & 26.7 \\
\hline Year dummies & 0.69 & 0.10 & 14.2 \\
\hline
\end{tabular}

Note: We define the percent of the full regression adj. R-squared explained by the industry dummies as (adjusted R-squared from the regression including only the industry dummies)/(adj. R-squared of the full specification). The alternative, (adj. R-squared from the regression including everything but the industry dummies)/(adj. R-squared of the full specification), would yield slightly higher percents.

While this regression analysis has used disaggregated industry data, it also is useful to consider broader aggregates. The results of this aggregation are provided in Table 3. Across the broadly aggregated sections it is clear that Energy and Manufactured Goods have by far the highest imported input shares at, on average, 43 percent and 38 percent of total inputs respectively. Non-manufactured goods, food, raw materials, and the distribution sector all have average imported input shares at or just below 20 percent. Across countries we confirm the observation that Ireland, at 52 percent, and the United States, at 6 percent, span the spectrum of intensities for the group of sixteen countries.

Comparable data analysis of expenditures on distribution services also generates interesting observations. First, we conduct a variance decomposition exercise across the most disaggregated industry level data (59 industries, 16 countries). As shown in Table 4, this decomposition explains substantially less of the sample variation than was the case when we examined patterns of imported input use. Industry fixed effects had the strongest explanatory power. There are common patterns across countries in the incidence of high and low distribution margin expenditures for industries. Distribution expenses are consistently high in Apparel (18), Leather (19), Furniture manufacturing (36), and Fishing and related services (5). Distribution expenses appear to be lowest on some commodity-type products and industries, such as Petroleum and Natural Gas Extraction (11), uranium, thorium, and metal ore mining (12 and 13), and non-automobile transportation equipment manufactures (35). 


\section{Table 3}

Imported Input Share

\begin{tabular}{|c|c|c|c|c|c|c|c|c|}
\hline & Year & $\begin{array}{c}\text { All } \\
\text { Industries }\end{array}$ & $\begin{array}{l}\text { Manufactured } \\
\text { Goods }\end{array}$ & $\begin{array}{c}\text { Non- } \\
\text { Manufacturing }\end{array}$ & Energy & Food & $\begin{array}{c}\text { Raw } \\
\text { Materials }\end{array}$ & $\begin{array}{l}\text { Distribution } \\
\text { Sector }\end{array}$ \\
\hline Austria & 2000 & 0.29 & 0.48 & 0.18 & 0.46 & 0.18 & 0.15 & 0.17 \\
\hline Belgium & 2000 & 0.35 & 0.53 & 0.23 & 0.61 & 0.34 & 0.32 & 0.28 \\
\hline Denmark & 2000 & 0.23 & 0.39 & 0.16 & 0.30 & 0.20 & 0.19 & 0.17 \\
\hline Finland & 2000 & 0.25 & 0.35 & 0.16 & 0.58 & 0.15 & 0.11 & 0.17 \\
\hline France & 2000 & 0.14 & 0.22 & 0.09 & 0.47 & 0.11 & 0.17 & 0.07 \\
\hline Germany & 2001 & 0.19 & 0.31 & 0.12 & 0.44 & 0.16 & 0.19 & 0.17 \\
\hline Hungary & 2000 & 0.44 & 0.63 & 0.21 & 0.71 & 0.20 & 0.16 & 0.21 \\
\hline Ireland & 1998 & 0.52 & 0.68 & 0.42 & 0.48 & 0.30 & 0.48 & 0.46 \\
\hline Italy & 2000 & 0.20 & 0.30 & 0.13 & 0.54 & 0.16 & 0.18 & 0.17 \\
\hline Netherlands & 2000 & 0.30 & 0.46 & 0.22 & 0.45 & 0.35 & 0.44 & 0.28 \\
\hline Norway & 2001 & 0.21 & 0.30 & 0.17 & 0.13 & 0.14 & 0.17 & 0.22 \\
\hline Portugal & 1999 & 0.24 & 0.40 & 0.13 & 0.36 & 0.25 & 0.06 & 0.15 \\
\hline Spain & 1995 & 0.18 & 0.27 & 0.11 & 0.40 & 0.12 & 0.08 & 0.08 \\
\hline Sweden & 2000 & 0.25 & 0.37 & 0.18 & 0.57 & 0.20 & 0.20 & 0.20 \\
\hline U. Kingdom & 1995 & 0.18 & 0.29 & 0.12 & 0.12 & 0.16 & 0.15 & 0.13 \\
\hline United States & 2002 & 0.06 & 0.09 & 0.03 & 0.28 & 0.04 & 0.07 & 0.03 \\
\hline Average & & 0.25 & 0.38 & 0.17 & 0.43 & 0.19 & 0.20 & 0.19 \\
\hline $\begin{array}{l}\text { Standard } \\
\text { Deviation }\end{array}$ & & 0.11 & 0.15 & 0.08 & 0.16 & 0.08 & 0.12 & 0.10 \\
\hline
\end{tabular}

\section{Table 4}

Distribution Expense Variance Decomposition

\begin{tabular}{|l|c|c|c|}
\hline \multicolumn{1}{|c|}{ Adjusted R-squared for the full regression specification with all dummy variables } & 0.49 \\
\hline & $\begin{array}{c}\text { Adj. R-squared for } \\
\text { regression excluding each } \\
\text { set of dummies }\end{array}$ & $\begin{array}{c}\text { Adj. R-squared for } \\
\text { regression with only each } \\
\text { set of dummies }\end{array}$ & $\begin{array}{c}\text { Percent of full regression } \\
\text { specification adjusted R2 } \\
\text { explained by each set of } \\
\text { dummies }\end{array}$ \\
\hline Industry dummies & 0.13 & 0.34 & 69.1 \\
\hline Country dummies & 0.44 & 0.13 & 26.9 \\
\hline Year dummies & 0.49 & 0.09 & 18.3 \\
\hline
\end{tabular}

Time fixed effects explain little of the variation observed in distribution expenditures. Each country in the sample typically had two years of distribution margins data included in the analysis. Of 30 industries with enough observations to examine trend, only 7 had statistically significant time trends. Among these industries, 4 had positive time trends (Agriculture, Mining, Manufacturing of Food products, and Pulp, Paper and Paper products) and 3 had negative time trends (Manufacturing of Radio and Television, Motor Vehicles, and Medical and Precision equipment). Thus, the number of industries with strong distribution expenditure trends was low, and the pattern of changes in distribution expenditures was not persistent for all industries in either a positive or negative direction. Hungary and Finland have the lowest overall level for distribution expenditures. On the other extreme, the U.S. had the largest distribution expenditures in the sample (0.29 in 2002). This observation contrasts sharply with what was 
observed for imported input use, where increasing globalization of production was readily apparent across many industries. Over the past decade, imported input use and globalization of production has grown substantially, while changes in distribution expenditures have been more diffuse and bidirectional.

One short-coming of this distribution margin data, as explained in Campa and Goldberg (2006), is that there is a trade-off in getting information expenditure margins at the industry-level and getting information relevant for the consumption of households. The total distribution margins with industry-level detail encompass margins on total final consumption. This total includes distribution margins for household consumption, investment, public sector, and export markets. In our modeling of CPI sensitivity to exchange rates and import prices we use the distribution expenditure specifically for the household sector, eschewing the more extensive industryspecific information used in the variance decomposition. In part, the country-fixed effects in the variance decomposition just discussed reflect the components of final demand in each country. Distribution margins in fixed capital formation and exports are substantially lower than those on household consumption.

\section{Calibrating Pass Through of Exchange Rates into Consumption Prices}

Pass through of exchange rates into consumer price indices has two main components. First, we require information on how exchange rates pass through into import prices. This information was presented in Section II, and in Table 1. Second, we require a model of import price transmission into consumer prices. This model was provided in Section III A, and is based on Campa and Goldberg (2006). In this section of the paper we focus on calibrating the model using our information on changes in key parameters, including sector distribution expenditure and imported input use. Our goal is to track, quantitatively and qualitatively, the sources of change in predicted pass-through of exchange rates into consumption prices. We begin by assuming relevant parameters for calibrating equations (4) to (6).

Assumptions are made for the values of demand elasticity $(\theta)$, the elasticities of substitution among groups of products, and elasticities of response to exchange rates of distribution margins and imported inputs. ${ }^{11}$ Our assumed estimate of the demand elasticity, $\theta$, is consistent with evidence on the steady state price over cost markups, defined by markup $=\theta /(\theta-1)$. Basu and Fernald (1997) find markups for United States industries in the range of 11 percent. Oliveira Martins, Scarpetta, and Pilat (1996) find markups ranging between 10 and 35 percent, in data spanning 14 OECD countries and 36 manufacturing industries. These markup values imply a range for $\theta$ between 10 and 4. For our calibration we assume $\theta=7$. Using higher demand elasticities would yield lower values of pass through into home tradables and now tradeable goods prices.

The simple model of equations (4) through (6) is able to explore many alternative specifications on substitution elasticities, changes to industry competitive structures, and state-contingent markups. Likewise, a range of assumptions could be made about the ability of producers to

\footnotetext{
11 The calibrations basically shut down the role of initial conditions and substitution between tradables and no tradables goods by setting the relative price terms to equal one in the calculations. Accordingly, values of $\phi$ do not matter for these calibrations.
} 
substitute between home-produced inputs and imported inputs when exchange rates alter the relative prices of inputs from different sources, or about pro-active adjustment of profit margins of distributors of goods. These important themes, explored at length in Campa and Goldberg (2006), are not emphasized here.

Our specific goal is to explore the changes in pass-through into consumer prices that are specifically attributable to changes in pass through at the border, changes in imported input use and distribution sector expenditures. With this objective in mind, we "shut down" some of the other forces which would influence exchange-rate transmission into the final consumption prices of goods. Specifically the initial relative prices of imported and home tradables, and of home tradables and no tradables, are assumed to be the same. Imported input shares are assumed inelastic with respect to exchange rates and are assumed to be identical across the production of no tradables and home tradables. Finally, distribution expenditures are assumed inelastic with respect to exchange rates, so that $\eta^{m(f: e), e}$ and $\eta^{m(h: e), e}=0$.

We focus on data for All Industries, Manufacturing, No manufacturing, Energy, Food, and Raw Materials, which are the industry groupings for which we also have information on import prices and exchange rate pass-through at the border. While there are eighteen countries for which we have been able to estimate exchange rate pass-through into import prices at this level of index disaggregation, changes in both imported input use and distribution expenditures are available only for ten of these countries.

Calibrated pass-through. Table 5 reports the calibrated pass-through elasticities into final prices of imports and domestically produced traded goods according to equations (5) and (6). These pass-through coefficients imply the transmission into final prices of a given percentage change in the import price at the border. The estimates use the imported input shares and distribution ratios calculated as described in the previous section for the years indicated in the second column of the table.

The pass-through transmission to final prices of imported products is relatively high and fluctuates for the aggregate of all industries between 0.68 for the United States and 0.9 for Hungary and Sweden. This means that, given a change in imported goods prices at a country's border, nearly 70 percent of this price signal will be transmitted to the final consumption prices of the imported goods in the United States, and nearly 90 percent in Hungary and Sweden. The two key determinants of variations in this rate of pass-through are the share of imported inputs in the production of non-traded services that enter the distribution sector, and the share of the distribution sector into final prices of the product. For a given share of imported inputs into the production of non-traded goods in the country, the higher the share of distribution costs the lower the rate of transmission into final prices. On the other hand as the share of imported inputs into non traded goods increases, so does the sensitivity of distribution costs to changes in import prices. 


\section{Table 5}

Pass-through of a change in import prices at the border into the consumption prices of imported and domestically-produced traded products

\begin{tabular}{|c|c|c|c|c|c|c|c|}
\hline \multicolumn{8}{|c|}{ For imported products } \\
\hline & Year & $\begin{array}{c}\text { All } \\
\text { Industries }\end{array}$ & Manufactured & $\begin{array}{c}\text { Non- } \\
\text { Manufactured }\end{array}$ & Energy & Food & Raw Materials \\
\hline Austria & 1995 & 0.851 & 0.858 & 0.809 & 0.842 & 0.831 & 0.875 \\
\hline Belgium & 1995 & 0.886 & 0.887 & 0.874 & 0.877 & 0.853 & 0.911 \\
\hline Denmark & 1995 & 0.825 & 0.819 & 0.851 & 0.884 & 0.821 & 0.760 \\
\hline Finland & 1995 & 0.887 & 0.881 & 0.918 & 0.900 & 0.762 & 0.976 \\
\hline Germany & 1995 & 0.844 & 0.852 & 0.784 & 0.863 & 0.757 & 0.764 \\
\hline Hungary & 1998 & 0.902 & 0.905 & 0.892 & 0.857 & 0.848 & 1.000 \\
\hline Ireland & 1998 & 0.939 & 0.930 & 0.987 & 1.000 & 0.939 & 0.974 \\
\hline Italy & 1995 & 0.847 & 0.857 & 0.754 & 0.864 & 0.744 & 0.932 \\
\hline Netherlands & 1995 & 0.878 & 0.873 & 0.899 & 0.928 & 0.849 & 0.876 \\
\hline Portugal & 1999 & 0.859 & 0.859 & 0.858 & 0.828 & 0.814 & 0.904 \\
\hline Spain & 1995 & 0.866 & 0.875 & 0.822 & 0.922 & 0.807 & 0.732 \\
\hline Sweden & 1995 & 0.903 & 0.891 & 0.948 & 0.901 & 0.858 & 0.966 \\
\hline U. Kingdom & 1955 & 0.846 & 0.833 & 0.925 & 0.967 & 0.750 & 0.914 \\
\hline United States & 1997 & 0.684 & 0.696 & 0.518 & 0.497 & 0.620 & 0.876 \\
\hline \multicolumn{8}{|c|}{ For domestically produced products } \\
\hline & Year & $\begin{array}{c}\text { All } \\
\text { Industries }\end{array}$ & Manufactured & $\begin{array}{c}\text { Non- } \\
\text { Manufactured }\end{array}$ & Energy & Food & Raw Materials \\
\hline Austria & 1995 & 0.354 & 0.496 & 0.276 & 0.372 & 0.211 & 0.291 \\
\hline Belgium & 1995 & 0.389 & 0.607 & 0.245 & 0.528 & 0.429 & 0.431 \\
\hline Denmark & 1995 & 0.259 & 0.463 & 0.144 & 0.401 & 0.201 & 0.194 \\
\hline Finland & 1995 & 0.259 & 0.376 & 0.149 & 0.517 & 0.192 & 0.151 \\
\hline Germany & 1995 & 0.195 & 0.295 & 0.137 & 0.307 & 0.218 & 0.142 \\
\hline Hungary* & 1998 & 0.443 & 0.661 & 0.273 & 0.668 & 0.273 & 0.169 \\
\hline Ireland & 1998 & 0.648 & 0.837 & 0.502 & 0.560 & 0.391 & 0.581 \\
\hline Italy & 1995 & 0.243 & 0.338 & 0.181 & 0.612 & 0.223 & 0.147 \\
\hline Netherlands & 1995 & 0.376 & 0.563 & 0.257 & 0.392 & 0.442 & 0.423 \\
\hline Portugal & 1999 & 0.306 & 0.489 & 0.184 & 0.454 & 0.329 & 0.087 \\
\hline Spain & 1995 & 0.227 & 0.329 & 0.151 & 0.475 & 0.163 & 0.128 \\
\hline Sweden & 1995 & 0.326 & 0.365 & 0.295 & 0.372 & 0.054 & 0.331 \\
\hline U. Kingdom & 1995 & 0.230 & 0.361 & 0.150 & 0.146 & 0.231 & 0.184 \\
\hline United States & 1997 & 0.068 & 0.101 & 0.042 & 0.262 & 0.058 & 0.069 \\
\hline
\end{tabular}

The numbers reported here are the estimated values of equations (5) and (6). The computation further assumes an elasticity of demand of 7 , and zero elasticities of exchange rate changes to distribution margins in home products, and to the share of imported inputs used in production.

Differences in calibrated pass-through across industries for a given country are relatively small. Such differences arise due to differences in the share of distribution costs in different sectors and these tend to be relatively small. Larger differences arise across countries. For instance, the United States has the highest share of distribution costs in the sample (see Table 5) and a low share of imported inputs in production in distribution services (see Table 3) leading to the result 
that the predicted transmission into final prices of imported goods is the lowest. On the other extreme, Hungary has the lowest share of distribution margins (0.07 in Table 5) and the second highest, after Ireland, ratio of imported inputs into production (0.44 in Table 3). Its rate of passthrough into final prices of imported products is 0.90 , the highest in the sample.

Pass-through into final prices of domestically produced traded goods is reported in the lower panel of Table 5. Transmission rates are significantly lower than the transmission rates for imported products. The transmission rates for all industries (column 3) fluctuate between 0.65 for Ireland and 0.07 for the U.S. Looking at equation (5), two are the key differences for the lower transmission rates. First, and most important, is the ratio of imported inputs into the production of domestic goods (the last term in the square brackets of equation [5]). The lower this ratio, the less sensitive are input costs to changes in prices of imported products and the weaker are cost pressures arising from exchange rates into the prices of domestically produced goods. The second factor is the importance of the distribution sector and the sensitivity of this sector to changes in import prices (the first term in the square brackets of equation [5]). The higher the sensitivity of the distribution sector to import prices, the higher also the passthrough into final prices of domestically produced goods.

The U.S. shows the lowest sensitivity of domestically produced goods prices. This is due mainly to two factors: its lowest sensitivity of final prices of imports reported above and to its lower share of imported inputs into production of domestic goods. In contrast, Hungary again shows the highest predicted sensitivity of the prices of domestically-produced goods to changes in the border prices of imported goods.

Differences across industries are much larger in the case of domestically produced goods. Transmission rates are substantially larger for Energy and Manufacturing than for the other three industries in almost all countries in the sample. This is mainly due to the higher ratio of imported inputs into the production of Manufacturing and Energy products relative to the other industries (see Table 3).

Changes over time in calibrated pass-through. To evaluate the evolution of changes in these transmission rates over time we compute the same transmission rates as those reported in Table 5 using the latest available information on distribution margins and imported input shares for each country. ${ }^{12}$ Table 6 reports the difference between the estimated values for equations (5) and (6) using data from these later years and the estimated transmission rates using 1995 data and reported in Table 5.

Increases in the pass-through for imported products can be due, following equation (6), to decreases in the share of distribution costs in the final price of imported products. Increases in the prices of non traded goods due to increases in the imported inputs used in the production of non traded goods can result in an increase in pass-through of exchange rates into final prices of imported products.

The results in the top-panel of Table 6 indicate that there has been an increase in the calibrated pass-through of movements in border prices of imports into the final prices of imported and domestically-produced goods for most countries. For aggregated imported goods, this increased

12 The year used for each country to calculate the measure of imported inputs is reported in Table 3 and the corresponding date for the share of distribution costs is reported in Table 5. 
transmission of border prices to final consumption prices has happened in all countries shown, with the exception of the United States, Italy, and, to a very small degree, Belgium and Sweden. The countries with an increase in the rate of transmission have this result mainly because imported inputs are more extensively used in the production of non-traded goods that factor into the costs of distribution services.

For the United States and Italy, the decline in border price transmission into the final prices of imported goods is a feature of Manufacturing, Food, and Raw Materials. For the United States, pass through into Non-manufactured imports and Energy imports rose, while it declined for these sectors in Italy. The share of imported inputs into production on no tradables in these countries has also increased, although relatively less than for other countries, in the last decade. Therefore, this lower calibrated sensitivity of the final consumption prices of imported goods has been mainly due to increases in expenditure on distribution services in these industries. In contrast, for the United States the substantial decrease in the distribution expenditures in Energy and Nonmanufacturing (of almost 25 percent) have resulted in a substantial increase in pass-through for those industries.

\section{Table 6}

Changes in implied pass-through into the consumption prices of imported and domesticallyproduced traded products

\begin{tabular}{|c|c|c|c|c|c|c|}
\hline \multicolumn{7}{|c|}{ For imported products } \\
\hline & Year & All Industries & Manufactured & $\begin{array}{c}\text { Non- } \\
\text { Manufactured }\end{array}$ & Energy & Food \\
\hline Austria & 0.016 & 0.009 & 0.063 & -0.013 & -0.029 & 0.121 \\
\hline Belgium & -0.003 & -0.002 & -0.011 & 0.033 & 0.007 & 0.044 \\
\hline Denmark & 0.025 & 0.027 & 0.019 & 0.037 & 0.014 & 0.022 \\
\hline Finland & 0.000 & 0.009 & -0.053 & -0.016 & -0.021 & -0.066 \\
\hline Germany & 0.017 & 0.017 & 0.008 & 0.011 & -0.005 & 0.012 \\
\hline Hungary & 0.036 & 0.023 & 0.106 & 0.057 & -0.001 & 0.090 \\
\hline Italy & -0.012 & -0.007 & -0.063 & -0.004 & -0.025 & -0.240 \\
\hline Netherlands & 0.007 & 0.002 & 0.021 & 0.017 & 0.001 & 0.097 \\
\hline Sweden & -0.001 & 0.012 & -0.066 & 0.002 & -0.042 & -0.026 \\
\hline US & -0.014 & -0.017 & 0.116 & 0.122 & -0.056 & -0.235 \\
\hline \multicolumn{7}{|c|}{ For domestically produced products } \\
\hline & Year & All Industries & Manufactured & $\begin{array}{c}\text { Non- } \\
\text { Manufactured }\end{array}$ & Energy & Food \\
\hline Austria & 0.023 & 0.102 & -0.036 & 0.207 & 0.054 & -0.115 \\
\hline Belgium & 0.058 & 0.052 & 0.072 & 0.222 & 0.022 & -0.040 \\
\hline Denmark & 0.043 & 0.020 & 0.066 & -0.038 & 0.063 & 0.077 \\
\hline Finland & 0.059 & 0.055 & 0.074 & 0.189 & 0.047 & -0.004 \\
\hline Germany & 0.055 & 0.083 & 0.041 & 0.232 & 0.013 & 0.114 \\
\hline Hungary & 0.088 & 0.098 & -0.025 & 0.189 & 0.010 & -0.019 \\
\hline Italy & 0.013 & 0.040 & 0.017 & 0.040 & 0.013 & 0.115 \\
\hline Netherlands & 0.014 & 0.015 & 0.019 & 0.148 & 0.006 & 0.097 \\
\hline Sweden & -0.005 & 0.089 & -0.047 & 0.319 & 0.234 & -0.085 \\
\hline US* & 0.008 & 0.020 & 0.001 & 0.077 & 0.003 & 0.022 \\
\hline
\end{tabular}

The numbers reported here are the difference between the estimated values of equations (5) and (6) for each country using data around 1995 (reported in Table 5) and using data for the year 2000. The computation further assumes an elasticity of demand of 4, and zero elasticities of exchange rate changes to distribution margins in home products, and to the share of imported inputs used in production. 
The bottom panel of Table 6 shows the imputed changes in the pass-through of import prices changes into the prices of domestic tradable products. Following equation (5), the two forces that would increase this pass through are increases in the share of imported inputs in production, whether for these goods specifically or for the distribution costs for domestically produced goods. This pass through also would rise if distribution services fall as share of the total production costs of the respective types of home produced goods. The results in Table 6 show that the imputed pass-through into home-produced tradable goods has increased in almost all industries and countries. The effect is positive in all cases in Manufacturing, Food and Energy industries. These changes have been larger in absolute value in Energy than in the other industries.

This rise in transmission of import price moves into the final prices of domestically-produced goods has been mainly due to changes in the ratio of imported inputs in the production in these industries. The increased in imported inputs in the production of these industries jointly with the increase in the use of imported inputs in the production of non-traded goods discussed above have both contributed to a higher sensitivity of final good prices of domestically produced goods to changes in import prices. The United States has had the smallest overall increase in its pass-through mainly due to its much lower pass-through rates among the countries in the sample, as reported in Table 5 above. However, in percentage terms its passthrough for all industries has increased by 12 percent, among the higher percentage increase of all countries in the sample.

The share of imported inputs in the production of domestic tradables has increased in all countries in the sample over the past decade. This increase has been proportionally larger in Energy and Manufacturing than in the other three industries. The share of imported inputs in the production of no tradables has also increased in the majority of countries. Only Sweden and Austria show a small decline in this ratio. In contrast, the change in the share of distribution costs has not been so homogeneous across countries. This share increased for Belgium, Finland, Italy and the U.S. The increase in distribution services has been primarily in Food (it increased for all countries) and in Manufacturing. This pattern results in a higher growth of pass through into the consumption prices of domestically-produced goods, in most cases, than for imported goods (see Table 6). This is especially the case for manufactured goods. Given a change in goods prices at the border, the implication is that an induced relative price effect is smaller. This observation may be relevant for discussions of expenditure switching induced by exchange rate changes.

Goldberg and Tille (2006) argue that an adjustment process to current account imbalances is likely to be asymmetric across the United States and its partners in trade, in particular because price sensitivity to exchange rates is expected to be substantially less in the United States. This would lead to relative prices of imports for the United States to move to a lesser degree with exchange rate fluctuations than the relative prices of United States trading partners. The results of Table 6 provide perspective on how this asymmetry has changed recently. In particularly, focusing only on manufacturing and the all industries columns of Table 6 , we observe that the increased transmission into prices was smaller for the United States than for other countries. This suggests that the asymmetry in adjustment to exchange rate movements may, all else equal, have gotten larger between the United States and some trading partners in the most recent decade. 


\section{Conclusions}

This paper has explored the channels for transmission of exchange rates into various types of consumption goods prices and into the aggregate level of prices across eighteen economies. First, we highlight transmission of exchange rates into the border prices of imported goods as the initial step in pass-through into final consumption prices of goods. We find that rates of exchange-rate pass through into import prices are measured with considerable precision for Manufactured goods, but are less precisely measured with respect to Non-manufactured goods, Raw materials, and Energy. The period since 1995 may have been one of marked changes in pass through into import prices of Manufactured goods, as we observe some countries with higher and others with lower rates of pass-through over the past decade.

Yet, these changes in transmission of exchange rates into the border prices of imports are not analogous to levels or directions of change in the transmission into the consumption prices of the same categories of goods. Thus, the second part of the paper is on the transmission of these border prices into final consumption prices. We take a model-based approach to transmission that highlights the role of sector expenditures on imported inputs and on distribution services. Examination of detailed cross-country data leads to the conclusion that changes in transmission into final consumption prices are associated more with the evolution of imported input use in production than to evolution in distribution expenditures at the industry level. In general, use of imported inputs in production grew sharply since the mid-1990s, increasing the sensitivity to exchange rates of the production costs of a broad spectrum of goods. By way of contrast, we observe that expenditures on distribution services have not trended consistently across countries or across industries.

The findings of generalized increases in the calibrated sensitivity of consumption prices of domestically-produced traded goods are important for understanding the potential for expenditure switching and trade adjustment to occur in the aftermath of changes in exchange rates. Goldberg and Tille (2006) argue that an adjustment process to current account imbalances is likely to be asymmetric across the United States and its partners in trade, in particular because price sensitivity to exchange rates is expected to be substantially less in the United States. This would lead to relative prices of imports for the United States to move to a lesser degree with exchange rate fluctuations than the relative prices of United States trading partners. It is useful to explore if this asymmetry is likely growing over time, or declining over time.

Our results imply that the calibrated sensitivity of consumption prices of domestically-produced tradables is rising at a faster rate than the price sensitivity of imported goods. If this is the case, the expenditure switching effects of exchange rate movements are weakened over time, primarily as a result of more integrated production internationally and greater use of imported inputs in production. All else equal, a greater movement in nominal exchange rates would be needed to generate the same elasticity of response of real trade flows. This is an issue that warrants further study.

Another implication of these findings is increases in the transmission into United States final prices have been smaller than into final prices in other countries. With exchange rate pass through into border prices already larger outside the United States, the changes over time have magnified the differences in transmission into final consumption prices. With the exchange rate as one instrument of trade balance adjustment, it may be the case that the task of expenditureswitching induced by exchange rates now falls even more heavily on the U.S. trade partners than on the United States. This too warrants further study. 


\section{References}

Antzoulatos, Angelos A. and Jiawen Yang (1996), "Exchange Rate Pass-through in U.S. Manufacturing Industries: A Demand Side Story," The International Trade Journal, 10(3), pp. 325-352.

Bacchetta, Philippe, and Eric van Wincoop (2003), "Why do Consumers Prices React Less Than Import Prices to Exchange Rates," Journal of the European Economics Association, 1, issue 2-3, April/May, pp. 662-670.

Bernhofen, Daniel M. and Peng Xu (2000), "Exchange Rates and Market Power: Evidence from the Petrochemical Industry,” Journal of International Economics, 52(2), pp. 283-297.

Blonigen, Bruce A. and Stephen E. Haynes (2002), "Antidumping Investigations and the Passthrough of Antidumping Duties and Exchange Rates," American Economic Review 92(4), pp. 1044-1061.

Burstein, Ariel, Joao Neves, and Sergio Rebelo (2003), "Distribution Costs and Real Exchange Rate Dynamics During Exchange Rate Based Stabilizations,” Journal of Monetary Economics.

Campa, José and Linda Goldberg (2005), “Exchange Rate Pass Through into Import Prices," Review of Economics and Statistics, November, 87 (4), pp. 679-690.

Campa, José and Linda Goldberg (2006), "Distribution Margins, Imported Inputs, and the Sensitivity of the CPI to Exchange Rates," NBER working paper \#12121 (March).

Campa, José, Linda Goldberg, and José Mínguez-González (2005), “Exchange Rate Pass Though into Euro-area Import Prices," Staff Reports No 219 (September), Federal Reserve Bank of New York.

Corsetti, Giancarlo and Luca Dedola (2005), "The Macroeconomics of International Price Discrimination," European Central Bank working paper No 176.

Daly, Deirdre, Rebecca Hellerstein, and Christina Marsh (2006), "Have U.S. Import Prices Become Less Responsive to Changes in the Dollar?," Current Issues in Economics and Finance, Federal Reserve Bankof New York, forthcoming.

Engel, Charles (1999), “Accounting for U.S. Real Exchange Rate Changes," Journal of Political Economy, Vol. 107, No 3, June, pp. 507-537.

Feenstra, Robert C. (1989), "Symmetric Pass-Through of Tariffs and Exchange Rates Under Imperfect Competition: An Empirical Test,” Journal of International Economics, 27(1/2), pp. 25-45.

Feenstra, Robert (1998), Integration of Trade and Disintegration of production in the global economy," The Journal of Economic Perspectives Vol 12, pp. 31-50.

Frankel, J.D. Parsley and S. Wei (2005), "Slow Pass-through Around the World: A New Import for Developing Countries?,” NBER Working Paper 11199.

Gagnon, Joseph and Jane Ihrig (2004), "Monetary policy and exchange rate pass-through," International Journal of Finance and Economics, Vol 9, pp. 315-338.

Gil-Pareja, Salvador (2003), "Pricing to Market Behavior in European Car Markets," European Economic Review, 47(6), pp. 945-962. 
Goldberg, Linda and Cedric Tille (2006), “The International Role of the Dollar and Trade Balance Adjustment,” NBER Working Paper \#12495 http://papers.nber.org/papers/W12495.

Goldberg, Pinelopi and Frank Verboven (2001), "The Evolution of Price Dispersion in the European Car Market," Review of Economic Studies, Vol 68, pp. 811-848.

Goldberg, Pinelopi and Michael Knetter (1997), "Goods Prices and Exchange Rates: What Have We Learned?," Journal of Economic Literature, Vol 35, pp. 1243-1292.

Gron, Anne and Deborah L. Swenson (1996), "Incomplete Exchange-Rate Pass-Through and Imperfect Competition: The Effect of Local Production," American Economic Review Papers and Proceedings, 86(2), pp. 71-76.

Gust, Christopher and Nathan Sheets (2006), "The Adjustment of Global External Imbalances: Does Partial Pass-through to Trade Prices Matter?," Board of Governors of the Federal Reserve System, International Finance Discussion Papers \#850, January.

Hellerstein, Rebecca (2004), "Who Bears the Cost of a Change in the Exchange Rate? The Case of Imported Beer," Staff Reports No 179, February, Federal Reserve Bank of New York.

Ihrig, Jane, Mario Marazzi, and Alexander Rothenberg (2006), "Exchange-Rate Pass-Through in the G-7 Countries," Board of Governors of the Federal Reserve System, International Finance Discussion Papers, No 851, January.

Marazzi, Mario, Nathan Sheets, and Robert Vigfusson et al. (2005), "Exchange Rate Pass Through to US Import Prices: Some New Evidence," Federal Reserve Board of Govenors, International Finance Discussion Paper, No 833, April.

Marazzi, Mario and Nathan Sheets (2006), "Declining Exchange Rate Pass-Through to U.S. Import Prices: The Potential of Global Factors," Federal Reserve Board of Governors, manuscript.

Marquez, Jaime and Charles Thomas (2006), "Measurement Matters for Modeling U.S. import Prices," Federal Reserve Board of Governors, manuscript.

Olivei, Giovanni P. (2002), "Exchange Rates and the Prices of Manufacturing Products Imported into the United States," New England Economic Review, First Quarter, pp. 3-18.

Osbat, Chiara (2005), "Sectoral Exchange Rate Pass Through in the Euro Area," Manuscript, European Central Bank (December).

Otani, Akira, Shigenori Shiratsuka, and Toyoichiro Shirota (2005), "Revisiting the Decline in the Exchange-Rate Pass-Through: Further Evidence from Japan's Import Prices,” IMES Discussion Paper Series No 2005-E-6, July.

Pollard, Patricia and Cletus Coughlin (2005), "Pass-through Estimates and the Choice of Exchange Rate,” Federal Reserve Bank of Saint Louis, Working Paper, 2003-004C.

Rauch, James (1999), “Networks versus Markets in International Trade," Journal of International Economics, Vol 48 pp. 7-35.

Yang, Jaiwen (1997), “Exchange Rate Pass-Through into U.S. Manufacturing Industries,” Review of Economics and Statistics, Vol 79, pp. 95-104. 


\section{DATA APPENDIX}

OECD import price series: Source: OECD Statistical Compendium. Quarterly time series of aggregate import price indices in local currency for 1975:Q1 to approximately 2004:Q4. We work with the maximum amount of data available by country in our analysis.

Effective Exchange Rate Indices. The nominal exchange rate index, is the trade weighted exchange rate index provides by the IMF. Code in IFS database: neu. The real effective exchange rate used is code reu. Regression analysis uses the inverse of the reported series, so that an increase in the exchange rate is a currency depreciation.

Foreign Price Index. We construct a consolidated export partners cost proxy by taking advantage of the IFS reporting of both real (reu) and nominal (neu) exchange rate series and computing $W_{t}^{x, j}=n e u_{t}^{j} \cdot P_{t}^{j} / r e u_{t}^{j}$ by each country in our sample. This gives us a measure of trading partner costs (over all partners $x$ of importing country $j$ ), with each partner weighted by its importance in the importing country's trade. The real effective exchange rate is calculated from Unit Labour Costs for developed countries by the IMF. Code in IFS database: reu. The consumer price indices from the International Financial Statistics. Code in IFS database: 64.

\section{Input-Output $(1 / 0)$ databases}

The Input-Output data for the different countries come from different sources:

- Data for Belgium, Finland, France, Germany, Greece, Italy, Netherlands, Spain, Sweden, and the United Kingdom come from the Eurostat National Accounts database. This database computes the input-output tables for these countries and reports a supply and a use table disaggregated to a total of 59 industries. These 59 industries include 22 manufacturing industries, 5 mining and extraction industries, 3 agriculture industries, 5 construction and energy industries, 8 trade and transport industries, and 17 service industries. We report distribution margin data for 29 manufacturing, mining and agriculture industries (we merge two mining industries into one, given their small production values in most countries).

- Data for Australia on input-output tables come from the Australian Bureau of Statistics. The data reports supply and final use tables for a total of 237 industries. We convert these industries into the CPA classification of 29 manufacturing, mining and agriculture industries.

- Data for the United States on input-output tables come from the "Benchmark Input Output Accounts for the US economy" (years 1992, and 1997). The U.S. input output accounts use a specific IO industry classification, which can then be transformed into the NIPA classification (National Income and Product Account Tables) and then aggregated into the CPA classification of 29 manufacturing, mining and agriculture industries used in the paper.

- Data for New Zealand on input output tables come from Statistics New Zealand. The data reports supply, use, and import tables for a total of 210 industries. We aggregate these industries into the CPA classification of 29 manufacturing, mining and agriculture industries. 


\section{Calculation of distribution margins:}

We compute the distribution margins for total supply in the industry as the ratio of the value of trade and transport margins to the value of total supply in the industry at purchasers' prices. Purchaser prices include the cost of supply at basic prices plus the distribution (retail, wholesale and transportation) costs plus net taxes on products. To the extent that taxation differs significantly across countries for the same industry and across industries within a country, distribution margins may not be perfectly comparable in all cases. See Campa and Goldberg (2006).

\section{Calculation of imported input ratios:}

The input-output tables report the value of the use matrix broken down the use of inputs by origin: domestic and imported. We calculate imported inputs into the production of each industry as the ratio between the total value of imported intermediate inputs by an industry to the value of total intermediate inputs.

Techniques to construct the imported intermediate flows matrix in the input-output tables vary by country. Most countries used to some extent the import proportionality assumption. This technique assumes that an industry uses an import of a particular product in proportion to its total use of that product. This assumption is limiting since some industries might be using inputs from domestic and import sources in different proportions than the average of the economy. Countries made use of this assumption at very different levels of aggregation. For instance, the OECD reports that Germany and Denmark made used of over 2000 different commodities, while the U.S. and Japan used slightly over 500 and the United Kingdom less than 200. 


\section{Appendix Table 1}

Long-run Import Price Pass Through

\begin{tabular}{|c|c|c|c|c|c|c|}
\hline & All Imports & $\begin{array}{l}\text { Manufact. } \\
\text { Goods }\end{array}$ & $\begin{array}{l}\text { Non-manufact. } \\
\text { Goods }\end{array}$ & Energy & Food & $\begin{array}{c}\text { Raw } \\
\text { Materials }\end{array}$ \\
\hline \multicolumn{7}{|l|}{ Pre-1995 } \\
\hline Australia & $0.62^{*}+$ & $0.89^{*}$ & $0.16+$ & -0.51 & $0.38^{*}+$ & $0.32+$ \\
\hline Austria & 1.01 & 0.55 & $2.27^{*}$ & 2.85 & 0.49 & $2.86^{*}$ \\
\hline Belgium & 1.03 & 0.6 & 0.56 & -3.13 & $1.36^{*}$ & $3.18^{*}+$ \\
\hline Denmark & $0.95^{\star}$ & $0.77^{*}$ & 1.10 & 1.37 & 0.74 & $1.95^{*}$ \\
\hline Finland & 0.72 & 0.6 & 1.43 & 2.01 & 1.06 & 0.27 \\
\hline France & $0.87^{*}$ & $0.86^{*}$ & 1.12 & 1.57 & $1.43^{*}$ & \\
\hline Germany & $1.00^{*}$ & $0.54^{*}+$ & $1.69^{*}$ & $2.64^{*}$ & $0.55^{*}+$ & $1.45^{\star}$ \\
\hline \multicolumn{7}{|l|}{ Hungary } \\
\hline Italy & $0.32+$ & $0.48+$ & -0.09 & -1.53 & $0.80^{\star}$ & 1.07 \\
\hline Netherlands & $0.93^{*}$ & $0.25+$ & $1.77^{*}$ & 2.36 & $0.73^{*}$ & $2.42^{*}+$ \\
\hline New Zealand & $0.36+$ & $0.29+$ & 0.99 & 1.91 & $0.04+$ & $-0.43+$ \\
\hline Norway & $0.97^{*}$ & $0.77^{*}$ & 0.31 & -0.21 & $-0.41+$ & 0.83 \\
\hline Portugal & $1.18^{*}$ & $1.06^{*}$ & $1.03^{*}$ & 1.06 & $1.14^{*}$ & $1.48^{*}+$ \\
\hline Spain & $0.66^{*}$ & $1.00^{*}$ & 0.58 & 0.06 & 0.95 & $1.16^{\star}$ \\
\hline Sweden & $0.32+$ & $0.56^{*}+$ & $-0.30+$ & $-0.88+$ & $0.79^{\star}$ & 0.28 \\
\hline UK & $0.45^{\star}+$ & $0.46^{*}+$ & $0.36+$ & 0.18 & $0.50^{*}+$ & $0.55^{*}+$ \\
\hline US & $0.44^{*}+$ & $0.47^{\star}+$ & $0.15+$ & $-0.22+$ & $0.24+$ & $0.36^{*}+$ \\
\hline Average & 0.74 & 0.63 & 0.82 & 0.60 & 0.67 & 1.18 \\
\hline St Deviation & 0.29 & 0.24 & 0.73 & 1.66 & 0.48 & 1.05 \\
\hline \multicolumn{7}{|l|}{ Post-1995 } \\
\hline Australia & $0.82^{*}$ & $0.93^{*}$ & 0.44 & 0.45 & $0.10+$ & 0.43 \\
\hline Austria & -1.40 & -1.30 & -2.55 & -7.60 & -1.11 & 3.02 \\
\hline Belgium & $0.25+$ & $0.14+$ & 0.47 & 2.08 & $-0.30+$ & 0.73 \\
\hline Denmark & $0.83^{*}$ & $0.45^{\star}+$ & $1.80^{*}$ & 3.67 & $1.30^{*}$ & 0.82 \\
\hline Finland & -0.16 & -0.24 & -1.58 & -3.37 & 2.50 & -1.70 \\
\hline France & 0.28 & $0.28+$ & 1.00 & 0.12 & 1.31 & \\
\hline Germany & 0.68 & $0.67^{*}$ & 0.63 & 0.54 & 0.44 & 0.93 \\
\hline Hungary & $0.78^{*}+$ & $0.79^{*}+$ & 0.67 & 0.89 & $0.63^{*}$ & 0.00 \\
\hline Italy & $0.85^{*}$ & $0.81^{*}$ & 1.82 & $4.11^{*}$ & 0.57 & 0.23 \\
\hline \multicolumn{7}{|l|}{ Netherlands } \\
\hline New Zealand & $0.12+$ & $0.19+$ & $-0.26+$ & -0.62 & $0.27+$ & $0.18+$ \\
\hline Norway & $0.09+$ & $0.06+$ & -0.23 & 1.90 & 1.02 & -1.27 \\
\hline Portugal & 1.96 & 1.66 & -0.64 & -16.58 & 6.47 & 7.55 \\
\hline Spain & $1.18^{*}$ & 1.70 & 0.84 & -3.18 & 2.23 & $3.18^{*}+$ \\
\hline Sweden & $0.21+$ & $0.61^{*}$ & $-1.74^{*}+$ & $-3.22^{*}+$ & $0.67^{*}$ & $-0.19+$ \\
\hline UK & $0.32^{*}+$ & $0.26+$ & 0.43 & 1.30 & $0.62^{*}$ & $0.08+$ \\
\hline US & $0.30^{*}+$ & $0.27^{*}+$ & 0.54 & 0.97 & $0.03+$ & 0.34 \\
\hline Average & 0.44 & 0.46 & 0.10 & -1.16 & 1.05 & 0.96 \\
\hline Std Deviation & 0.71 & 0.71 & 1.22 & 5.07 & 1.70 & 2.23 \\
\hline
\end{tabular}

* indicates different from 0 with 10\% significance.

+ indicates different from 1 with 10\% significance. 


\section{Appendix Table 2}

Overview of data on imported inputs and distribution margins, by country and industry

\begin{tabular}{|l|ll|ll|}
\hline \multicolumn{3}{|c|}{ Imported Input Data Availability } & \multicolumn{2}{c|}{ Distribution Margin Data Availability } \\
\hline \multicolumn{1}{|c|}{ Country } & \multicolumn{1}{c|}{ Years } & \multicolumn{1}{c|}{ Number of Industries } & \multicolumn{1}{c|}{ Years } & \multicolumn{1}{c|}{ Number of Industries } \\
\hline Austria & 1995,2000 & $1995: 54,2000: 56$ & 1995,2001 & $1995: 27,2001: 29$, in both: 27 \\
Belgium & 1995,2000 & $1995: 54,2000: 55$ & 1995,2001 & $1995: 29,2001: 29$, in both: 29 \\
Denmark & 1995,2000 & $1995: 55,2000: 55$ & 1995,2000 & $1995: 27,2000: 28$, in both: 27 \\
Finland & 1995,2000 & $1995: 56,2000: 56$ & 1995,2002 & $1995: 29,2002: 30$, in both: 29 \\
France & 2000 & $2000: 57$ & 1995,2001 & $1995: 30,2001: 29$, in both: 29 \\
Germany & 1995,2001 & $1995: 57,2001: 56$ & 1995,2001 & $1995: 30,2001: 30$, in both: 30 \\
Greece & & & 1995,1999 & $1995: 30,1999: 30$, in both: 30 \\
Hungary & 1998,2000 & $1998: 57,2000: 57$ & 1998,2000 & $1998: 30,2000: 30$, in both: 30 \\
Ireland & 1998 & $1998: 55$ & 1998 & $1998: 26$ \\
Italy & 1995,2000 & $1995: 57,2000: 57$ & 1995,2001 & $1995: 29,2001: 29$, in both: 29 \\
Netherlands & 1995,2000 & $1995: 55,2000: 55$ & 1995,2001 & $1995: 30,2001: 30$, in both: 30 \\
Norway & 2001 & $2001: 57$ & 2002 & $2002: 29$ \\
Portugal & 1999 & $1999: 56$ & 1995,1999 & $1995: 28,1999: 28$, in both: 28 \\
Spain & 1995 & $1995: 57$ & 1995,2000 & $1995: 29,2000: 29$, in both: 29 \\
Sweden & 1995,2000 & $1995: 48,2000: 55$ & 1995,2001 & $1995: 29,2001: 29$, in both: 29 \\
UK & 1995 & $1995: 57$ & 1995,2001 & $1995: 29,2001: 29$, in both: 29 \\
US & 1997,2002 & $1997: 30,2002: 30$ & 1992,1997 & $1992: 29,1997: 29$, in both: 27 \\
\hline
\end{tabular}




\section{Appendix Table 3}

Industry Names

For disaggregated imported input and distribution margin data

\begin{tabular}{|c|c|c|}
\hline Number & Industry Name & Mapping \\
\hline $\mathrm{a} 01$ & Agriculture, hunting and related service activities & non-manufacturing \\
\hline $\mathrm{a} 02$ & Forestry, logging and related service activities & $\begin{array}{l}\text { non-manufacturing, raw } \\
\text { materials }\end{array}$ \\
\hline b05 & $\begin{array}{l}\text { Fishing, operation of fish hatcheries and fish farms; service activities } \\
\text { incidental to fishing }\end{array}$ & non-manufacturing \\
\hline ca10 & Mining of coal and lignite; extraction of peat & $\begin{array}{l}\text { non-manufacturing, raw } \\
\text { materials }\end{array}$ \\
\hline ca11 & $\begin{array}{l}\text { Extraction of crude petroleum and natural gas; service activities } \\
\text { incidental to oil and gas extraction excluding surveying }\end{array}$ & $\begin{array}{l}\text { non-manufacturing, raw } \\
\text { materials }\end{array}$ \\
\hline ca12+ & Mining of uranium and thorium ores & $\begin{array}{l}\text { non-manufacturing, raw } \\
\text { materials }\end{array}$ \\
\hline cb13 & Mining of metal ores & $\begin{array}{l}\text { non-manufacturing, raw } \\
\text { materials }\end{array}$ \\
\hline cb14 & Other mining and quarrying & $\begin{array}{l}\text { non-manufacturing, raw } \\
\text { materials }\end{array}$ \\
\hline da15 & Manufacture of food products and beverages & manufacturing, food \\
\hline da16 & Manufacture of tobacco products & manufacturing, food \\
\hline $\mathrm{db} 17$ & Manufacture of textiles & manufacturing \\
\hline $\mathrm{db} 18$ & Manufacture of wearing apparel; dressing; dyeing of fur & manufacturing \\
\hline dc19 & Tanning, dressing of leather; manufacture of luggage & manufacturing \\
\hline dd20 & $\begin{array}{l}\text { Manufacture of wood and of products of wood and cork, except furniture; } \\
\text { manufacture of articles of straw and plaiting materials }\end{array}$ & manufacturing \\
\hline de21 & Manufacture of pulp, paper and paper products & manufacturing \\
\hline de22 & Publishing, printing, reproduction of recorded media & manufacturing \\
\hline df23 & Manufacture of coke, refined petroleum products and nuclear fuel & manufacturing, energy \\
\hline dg24 & Manufacture of chemicals and chemical products & manufacturing \\
\hline dh25 & Manufacture of rubber and plastic products & manufacturing \\
\hline $\operatorname{di26}$ & Manufacture of other non-metallic mineral products & manufacturing \\
\hline dj27 & Manufacture of basic metals & manufacturing \\
\hline dj28 & $\begin{array}{l}\text { Manufacture of fabricated metal products, except machinery and } \\
\text { equipment }\end{array}$ & manufacturing \\
\hline dk29 & Manufacture of machinery and equipment n.e.c. & manufacturing \\
\hline $\mathrm{dl30}$ & Manufacture of office machinery and computers & manufacturing \\
\hline $\mathrm{dl31}$ & Manufacture of electrical machinery and apparatus n.e.c. & manufacturing \\
\hline $\mathrm{dl} 32$ & $\begin{array}{l}\text { Manufacture of radio, television and communication equipment and } \\
\text { apparatus }\end{array}$ & manufacturing \\
\hline dl33 & $\begin{array}{l}\text { Manufacture of medical, precision and optical instruments, watches and } \\
\text { clocks }\end{array}$ & manufacturing \\
\hline dm34 & Manufacture of motor vehicles, trailers and semi-trailers & manufacturing \\
\hline dm35 & Manufacture of other transport equipment & manufacturing \\
\hline dn36 & Manufacture of furniture; manufacturing n.e.c. & manufacturing \\
\hline dn37 & Recycling & non-manufacturing \\
\hline e40* & Electricity, gas, steam and hot water supply & $\begin{array}{l}\text { non-manufacturing, } \\
\text { energy }\end{array}$ \\
\hline e41* & Collection, purification and distribution of water & non-manufacturing \\
\hline $\mathrm{f} 45^{*}$ & Construction & non-manufacturing \\
\hline g50* & Sale, maintenance and repair of motor vehicles & non-manufacturing \\
\hline g51* & Wholesale trade and commission trade, except of motor and motorcycles & non-manufacturing \\
\hline g52* & $\begin{array}{l}\text { Retail trade, except of motor vehicles, motorcycles; repair of personal } \\
\text { and household goods }\end{array}$ & non-manufacturing \\
\hline
\end{tabular}




\begin{tabular}{|l|l|l|}
\hline h55* & Hotels and restaurants & non-manufacturing \\
\hline $\mathrm{i} 60^{*}$ & Land transport; transport via pipelines & non-manufacturing \\
\hline $\mathrm{i} 61^{*}$ & Water transport & non-manufacturing \\
\hline $\mathrm{i} 62^{*}$ & Air transport & non-manufacturing \\
\hline $\mathrm{i} 63^{*}$ & Supporting and auxiliary transport activities; activities of travel agencies & non-manufacturing \\
\hline $\mathrm{i} 64^{*}$ & Post and telecommunications & non-manufacturing \\
\hline $\mathrm{j} 65^{*}$ & Financial intermediation, except insurance and pension funding & non-manufacturing \\
\hline $\mathrm{j} 66^{*}$ & Insurance and pension funding, except compulsory social security & non-manufacturing \\
\hline $\mathrm{j} 67^{*}$ & Activities auxiliary to financial intermediation & non-manufacturing \\
\hline $\mathrm{k} 70^{*}$ & Real estate activities & non-manufacturing \\
\hline $\mathrm{k} 71^{*}$ & Renting of machinery and equipment without operator and of personal & non-manufacturing \\
\hline $\mathrm{k} 72^{*}$ & Cond household goods & \\
\hline $\mathrm{k} 73^{*}$ & Research and development & non-manufacturing \\
\hline $\mathrm{k} 74^{*}$ & Other business activities & non-manufacturing \\
\hline $175^{*}$ & Public administration and defence; compulsory social security & non-manufacturing \\
\hline $\mathrm{m} 80^{*}$ & Education & non-manufacturing \\
\hline n85* & Health and social work & non-manufacturing \\
\hline $090^{*}$ & Sewage and refuse disposal, sanitation and similar activities & non-manufacturing \\
\hline $091^{*}$ & Activities of membership organization n.e.c. & non-manufacturing \\
\hline $092^{*}$ & Recreational, cultural and sporting activities & non-manufacturing \\
\hline $093^{*}$ & Other service activities & non-manufacturing \\
\hline p95+* & Private households with employed persons & non-manufacturing \\
\hline
\end{tabular}

+ Excluded from Imported input time trend regressions because of insufficient observations. 


\section{Appendix Table 4}

Distribution Margin Share

\begin{tabular}{|lccccccc|}
\hline & Year & $\begin{array}{c}\text { All } \\
\text { Industries }\end{array}$ & $\begin{array}{c}\text { Manufactured } \\
\text { Goods }\end{array}$ & $\begin{array}{c}\text { Non- } \\
\text { manufactured } \\
\text { Goods }\end{array}$ & Energy & Food & $\begin{array}{c}\text { Raw } \\
\text { Materials }\end{array}$ \\
\hline Austria & 2001 & 0.14 & 0.14 & 0.14 & 0.19 & 0.21 & 0.10 \\
Belgium & 2001 & 0.14 & 0.13 & 0.16 & 0.11 & 0.16 & 0.14 \\
Denmark & 2000 & 0.16 & 0.16 & 0.14 & 0.08 & 0.17 & 0.22 \\
Finland & 2002 & 0.12 & 0.12 & 0.15 & 0.12 & 0.28 & 0.13 \\
France & 2001 & 0.12 & 0.12 & 0.12 & 0.10 & 0.17 & 0.04 \\
Germany & 2001 & 0.14 & 0.13 & 0.21 & 0.12 & 0.25 & 0.22 \\
Greece & 1999 & 0.20 & 0.20 & 0.15 & 0.18 & 0.20 & 0.07 \\
Hungary & 2000 & 0.07 & 0.08 & 0.00 & 0.10 & 0.18 & -0.11 \\
Ireland & 1998 & 0.09 & 0.10 & 0.02 & & 0.09 & 0.04 \\
Italy & 2001 & 0.16 & 0.15 & 0.31 & 0.14 & 0.28 & 0.31 \\
Netherlands & 2001 & 0.13 & 0.14 & 0.09 & 0.06 & 0.17 & 0.03 \\
Norway & 2002 & 0.17 & 0.19 & 0.12 & 0.17 & 0.20 & 0.06 \\
Portugal & 1999 & 0.14 & 0.14 & 0.15 & 0.18 & 0.19 & 0.10 \\
Spain & 2000 & 0.13 & 0.13 & 0.18 & 0.07 & 0.20 & 0.10 \\
Sweden & 2001 & 0.11 & 0.11 & 0.13 & 0.11 & 0.20 & 0.07 \\
UK & 2001 & 0.21 & 0.22 & 0.10 & 0.05 & 0.28 & 0.07 \\
US & 1997 & 0.29 & 0.29 & 0.33 & 0.34 & 0.39 & 0.32 \\
Average & & $\mathbf{0 . 1 5}$ & $\mathbf{0 . 1 5}$ & $\mathbf{0 . 1 5}$ & $\mathbf{0 . 1 3}$ & $\mathbf{0 . 2 1}$ & $\mathbf{0 . 1 1}$ \\
St. Deviation & & $\mathbf{0 . 0 5}$ & $\mathbf{0 . 0 5}$ & $\mathbf{0 . 0 8}$ & $\mathbf{0 . 0 7}$ & $\mathbf{0 . 0 7}$ & $\mathbf{0 . 1 1}$ \\
\hline
\end{tabular}

